\title{
LOGISTICS COSTS IN THE PRACTICE OF POLISH PRODUCTION COMPANIES OF THE SME SECTOR
}

\section{Michal Biernacki}

Wroclaw University of Economics, Wroclaw, Poland

\begin{abstract}
:
Logistics costs and logistics cost accounting represents a distinct segment of modern economic practice, addressed at length in professional literature. Costs associated with logistics represent one of the fundamental measures of effectiveness for companies. They are also a good indicator of their ability to control and modernise their logistic processes. This aspect of company operation ought precisely to be defined. The principal reason is thats any inadequacies may lead to errors in formal interpretations of the levels or structure of logistics costs. Potential consequences of such poor judgement include the loss of competitive advantage, loss of market share or reduction of the scale of company operations. The paper presents results of empirical studies on separation of logistics costs and their impact on business operations of production companies of the SME sector in Poland. The research methodology was supplemented by literature studies, survey analysis, and deduction/induction methods.
\end{abstract}

Keywords:

costs, logistics cost, SME

\section{THE SCOPE AND DEFINITION OF LOGISTICS COSTS}

Before delving into scientific explorations of the logistics costs accounting, it is necessary to provide a precise definition of logistics costs. A standardised definition of the scope and the content of this particular segment of company costs is fairly difficult to establish. Disparities are mostly observable in the existing definitions of the term, interpretations of its content, range or structure, and also in the approaches to valuation of individual elements of logistics costs.

The lack of full transparency and of general agreement in defining the scope and the range of costs associated with logistics operations is particularly evident in the evaluation of cost items that representi the cost of: logistics, logistic management, logistic system, logistic transformation, material flows and the cost of product/ information circulation, freight runs, and supply chains. The observed disparities are mainly attributable to the lack of clear distinctions between the above elements, and to the lack of precision, as some of the above terms are often used interchangeably with others [Twaróg 2003, p.25].

One of the earliest attempts at a scientific evaluation of professional literature on the subject of logistics costs in Poland can be found in M. Kufel. The author relates logistics costs to the cost of internal flows of materials. The study has been responsible for the wide popularisation of the thesis that logistics costs become the central costing category in the 'material-and-information-flow' approach to management. M. Kufel defines logistics costs as a detailed costing category reflecting the economic (pecuniary) loss of company material substance, and attributed to the planning, realisation and control of non-technological processes involving spatial or temporal movement of all forms of materials [Kufel 1990, p.38]. 
A.Weselik insists on the use of the phrase "logistics cost" as the only term to offer consistency with the principles of accounting [Weselik 1993, p.23]. The conclusion was based on analytical evaluations of Polish terms "koszty logistyczne” vs. „koszty logistyki”, as direct translations of the English (logistic costs vs. logistics costs) and German counterparts Logistische Kosten vs. Logistikkosten. According to Weselik, the use of the term "logistic costs" would invariably lead to the constitution of a new costing category. Introducing the notion of logistics costs [Weselik 1999, p.10] helps avoid this problem, since cost accounting in this case would only need to be extended to register a new set of company activities.

For J. Kwest, logistics costs should comprise the following:

- planned cost of logistics to cover, among other things, the cost associated with transfer of supplies, the cost of producing, maintaining and replenishing the stock, transport and warehouse costs, credit interest expenditures, cost of information;

- incidental and unscheduled logistics costs, including the cost associated with the maintenance of excess inventory and credits (warehousing, servicing, interest accrued on stock and credits) and the cost associated with ineffective organisation of shipments (non-economic batches);

- loss generated by poor material management - e.g. stoppage due to late receipt, penalties for misplaced or misdirected shipment [Twaróg 2003, pp.26-27].

B. Szałek postulates the following structure of logistics costs:

- direct costs (transportation, warehouses, stock, communications) and indirect costs;

- fixed and unscheduled expenditures;

- cost of supply, production, and distribution;

- material and immaterial costs;

- cost of logistic management and the cost of activities delegated to third parties by logistic services;

- strictly logistic costs [Szałek 1994, p. 46].

Cz. Skowronek postulates that logistics costs should include pecuniary representations of depletion in human labour, means of labour and objects of labour, alongside with financial expenses and other negative effects of extraordinary nature incurred in relation to the flow of material goods, i.e. raw materials, production materials, finished products and other supplies (including internal and external flow), and stock maintenance [Skowronek... 1995, p.229].

M. Nowicka-Skowron in her publication presents further arguments for the complexity of categorisations employed in relation to logistics costs. In her view, proper identification of logistics costs should be directly related to the sources of each such expenditure in each phase of the production process, namely:

- acquisition of materials, semi-products and other third-party supplies;

- external and internal transportation of goods;

- production planning, to determine the intensity of material flows in production phase;

- warehousing of semi-products, finished products, materials, and waste from production;

- transfer of finished products to recipients [Twaróg 2003, p.28]

As suggested by the above statement, the complexity of the logistic processes and their impact upon company operation will naturally generate certain costs. These, in turn, will stimulate operating changes and contribute to the total reduction of the company gross financial result. Hence, logistics costs can also be categorised as follows:

- operating costs - recurring expenditures, closely related to the scale and intensity of company operations;

- strategic costs - one-time expenditures unrelated to the current scale and intensity of company operations (in a short-term perspective).

O.Duck, H.Krause and C.Schulte identify three fundamental types of costs deemed to exert a significant impact upon company financial result, namely:

- material costs - all types of expenditure generated in relation to the flow of supplies and goods, such as raw materials, supplementary materials, fuels, semi-products, and finished products;

- costs of annuity capitalisations - cost of interests accrued on capital tied up in stock, but also cost related to value depreciation of goods held in stock, and the cost of storage;

- general material costs - combined costs across all departments involved in materials and goods management, i.e. logistics and supply services, including cost of transportation and packaging, cost of electronic data processing, cost of waste disposal [Duck... 1997-2001, p.1].

Due to their complex structure, logistics costs can also be organised into:

- cost incurred in relation to shipment of supplies and goods (to warehouses or to final recipients);

- cost related to the maintenance of warehouse facilities and cost generated by other departments involved in material management;

- cost related to the transfer of data on materials and final products, transportation, and product operation (control); 
- cost related to the disposition of final products, transportation and product exploitation capabilities;

- cost of capital tied up in fixed assets and in working capital [Twaróg 2003, p.53].

Since the practical application of logistics costs dictates the use of precise target objectives, great significance should be attached to structural organisation of this type of expenditure by logistic phases of their origin, by logistic processes, and by their share in total consumption of production factors.

P.Blaik employed standard principles of cost accounting, knowledge of logistic systems in production companies, type of operation, and bookkeeping standards and mechanisms in his classification of logistics costs into:
- generic costs;

- cost of flows, phases and origins;

- cost of relations with basic types of logistic processes;

- cost of changes in the volume of material flows or supplies [Blaik 2001, pp.300-304].

The category of generic costs reflects recording of costs by type. Records by phase separate logistics cost into three sub-sections, representing cost generated in relation to supplies, production, or distribution. The latter is also adjusted against the overview of expenditures by their origin. Fig. 1 presents a model structure of material management expenditures as part of a logistic system in a production company.

Figure 1. Structure of costs associated with material supply

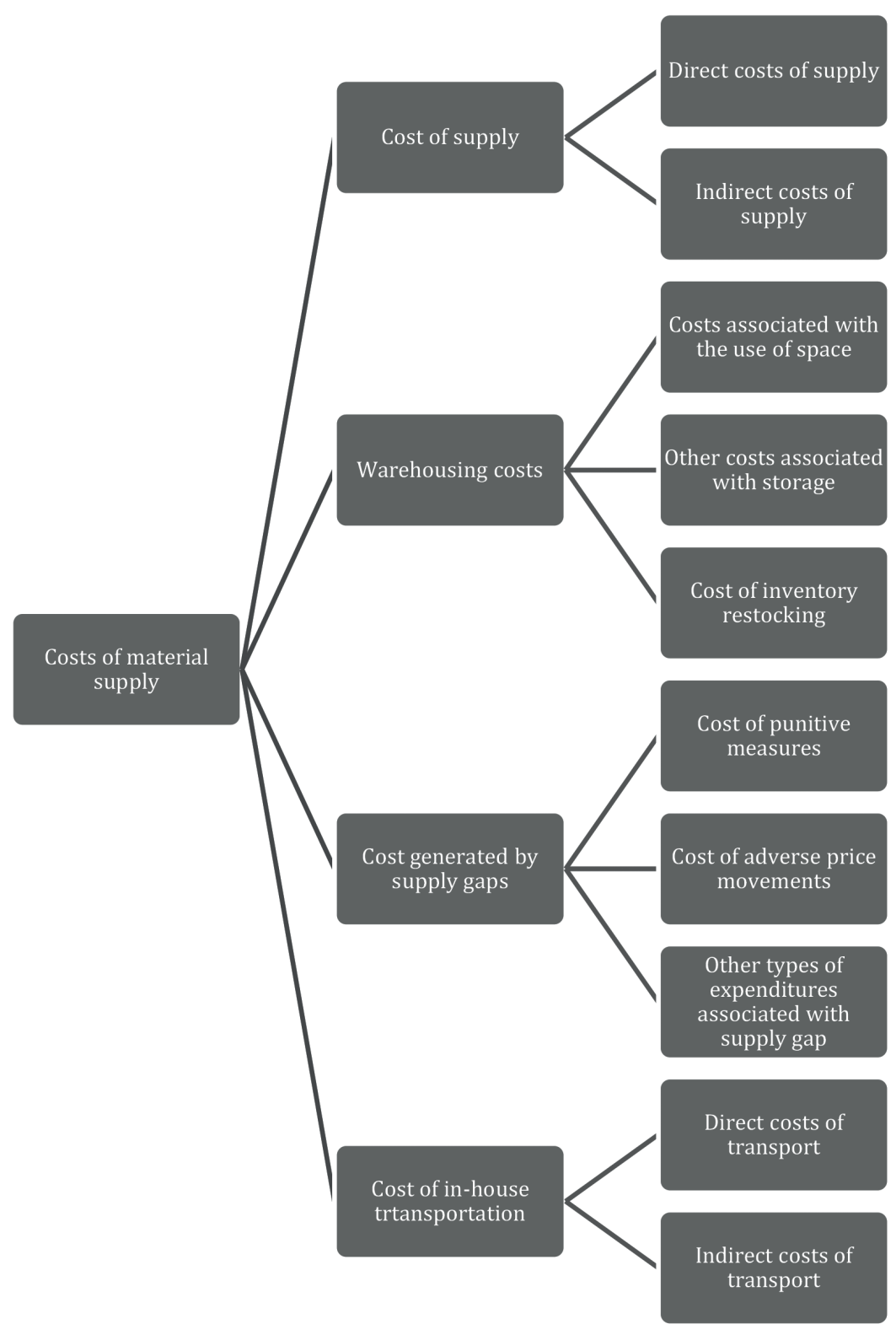


S. Abt postulates the following division and structure of logistics costs into:

- cost by goods flow phase and by cost origin

- supply phase

» supply department costs;

» warehousing department costs;

» transportation costs;

- production phase

» production planning costs;

» material flow management costs;

» in-house transportation costs;

- distribution phase

» sales department costs;

" warehousing department costs;

» cost of transport and forwarding;

- cost by group (segment) of logistic operations

- cost of physical transfer of goods

$»$ in-house transportation and maintenance;

» transportation services;

» forwarding;

» damage in transport

- cost of stock

» tied-up capital;

» warehouse maintenance;

» restocking;

» inventory obsolescence (both physical and moral);

" lost profit caused by inventory depletion;

» packaging and labelling;

» quality control

- cost of information processes

» value depreciation (hardware and software);

» energy and material consumption;

» third-party services;

》 logistic marketing;

» administration of orders [Abt 1998, p. 301]

In a model approach, classification of logistics costs includes the following three groups:

- cost of physical transfer of materials;

- cost of inventory (stock);

- cost of information processes [Twaróg 2003, p.60].

P. Blaik presents a general approach to the structure of total logistics costs using the following mathematical formula [Blaik 2001, p. 304]:

$\mathrm{K}_{\mathrm{L}}=\mathrm{K}_{\mathrm{ZP}}+\mathrm{K}_{\mathrm{SP}}+\mathrm{K}_{\mathrm{M}}+\mathrm{K}_{\mathrm{T}}+\mathrm{K}_{\mathrm{KZ}}+\mathrm{K}_{\mathrm{PP}}+\mathrm{K}_{\mathrm{PI}}+\mathrm{K}_{\mathrm{O}}+\mathrm{K}_{\mathrm{NS}}$, where:

$\mathrm{K}_{\mathrm{L}}$ - logistics costs;

$\mathrm{K}_{\mathrm{ZP}}$ - costs associated with formulation, planning, control and management of product and material flows (flow management costs);

$\mathrm{K}_{\mathrm{SP}}$ - logistic costs associated with planning and management of programmes and structure of production and realisation of orders;

$\mathrm{K}_{\mathrm{M}}$ - cost of warehousing;

$\mathrm{K}_{\mathrm{T}}$ - cost of transportation;

$\mathrm{K}_{\mathrm{KZ}}$ - cost of inventory (stock) management,

$\mathrm{K}_{\mathrm{PP}}$ - cost involved in preparation of products for sale and shipment (packaging, handling, etc.),

$\mathrm{K}_{\mathrm{PI}}$ - cost generated by information flows (communications) and processing of orders,

$\mathrm{K}_{\mathrm{O}}$ - cost of product servicing and logistic services,

$\mathrm{K}_{\mathrm{NS}}$ - cost of failures - excessive investment, supplementary cost transferred to third-party partners (suppliers, recipients) and lost profit.

The alternative concept of global logistics costs is based on the assumption that all the company operations conducted with regard to physical movement of raw materials, production components and finished products should be perceived as a whole, rather than a set of individual units. This approach results in global determination of all items on the list of costs for all logistic decisions made. One of the most important goals behind this concept is to identify costing variants burdened with the lowest possible global cost without detriment to the expected quality of customer service [Beier, Rutkowski 1993, p. 30]. This approach is closely related to the concept of cost interdependence, which holds that changes in logistic operations may generate increases in some cost items in parallel with decreases in other items on the list of costs. The ultimate goal here is to ensure an effective decrease in global cost with no detriment to the expected quality of customer service.

Global logistics costs (GLK) attached to the servicing of markets can be represented by the following formula [Beier, Rutkowski 1993, p. 64]:

Global logistics costs $=$ Cost of transport + Cost of supply in transit + Cost of warehousing and servicing of orders + Cost of inventory (stock) held by the company

Information related to logistics costs can be separated into two distinct groups. The first group represents costs generated by dynamic properties of material flows (transit processes may affect not only the location of materials, but also their form and characteristics), whereas the other describes costs related to static properties of material flows (i.e. for materials outside of transit, such as those kept as 
part of company inventory). The most important determinants in both of the above groups include the following:

- human work expenditure;

- energy consumption;

- the use of machinery and infrastructure in transportation, warehousing, etc.;

- capital tied up in stock;

- the use of premises or parts thereof;

- consumption of supplementary materials;

- the associated wastage and material loss in flow;

- various forms of payments and dues [Twaróg 2003, p.94].

In addition to the above, professional literature makes ample reference to the concept of logistics external costs, generated predominantly by two sources:

- operation of the existing infrastructure (systems of: logistics, transportation, warehousing, communications, information);

- introduction of new elements to the logistic infrastructure - these may generate negative effects, such as increase in the use of available space) [Kisperska-Moroń...2002, p.20].

External costs of logistic processes fall under technical costs or monetary costs. The external technical costs of logistics are those imposed by a single producer to the detriment of other actors. They are generated as a side effect of the core operating activities, for example - in the form of air pollution. Monetary costs, on the other hand, represent effects observed by other producers following an increase in productive output by a single competitor. Such a scenario contributes to the general increase in prices of production materials and components for the entire segment of production. In logistic operations, such a scenario may lead to increased demand for logistic services [Kisperska-Moroń...2002, p.21].

\section{RESEARCH FINDINGS}

The main body of research reported in this paper was conducted between March and August 2018 in the form of electronic surveys distributed among companies of strictly productive profile of operation, and representatives of the Polish SME segment. A total of 578 surveys were sent, with 239 valid responses. The following queries were included in the survey:

1. Does your company examine logistics costs in separation from other costs?

2. If not, are there plans to introduce such a separation of logistics costs within the next year?

3. Does your company utilise the concept of total logistics costs?
4. If so, does the separation of costs include the following subcategories:

a. costs of flows management;

b. logistic costs of planning and management of programmes and structure of production, and the realisation of orders;

c. cost of warehousing;

d. cost of transportation;

e. cost of inventory management,

f. cost involved in the preparation of products for sale and shipment (packaging, handling, etc.),

g. cost generated by information flows (communications) and processing of orders,

h. cost of product servicing and logistic services,

i. cost of failures - excessive investment, supplementary cost transferred to third-party partners (suppliers, recipients) and lost profit.

5. Does your company utilise the concept of global logistics costs?

6. Does your company separate external costs of logistics?

7. Does the separation and calculation of logistics costs (if applicable) provide tangible benefits in terms of in-house cost management effectiveness?

8. Does the separation and calculation of logistics costs (if applicable) provide tangible improvements in terms of customer service?

9. Does the separation and calculation of logistics costs (if applicable) provide tangible improvements of production processes and their effectiveness?

Of all the valid responses received, $43 \%$ companies reported effective separation of logistics costs from other types of cost (Fig. 2), with only $10 \%$ of the remaining companies intending to introduce such separation within the next year (Fig. 3). Of those companies that utilise effective separation of logistics costs, only $34 \%$ reported the use of total logistics costs (Fig. 4), and as many as $76 \%$ of the latter employed an effective separation of all analytical cost. In addition, companies which reported the use of such detailed classification of costs, i.e. total logistics costs with separation into analytical categories, included the following categories: flow management costs (50\%); logistic costs associated with planning and management of programmes and structure of production, and realisation of orders (100\%); warehousing costs (100\%); transportation costs (100\%); cost of inventory management (100\%); cost involved in preparation of products for sale and shipment (packaging, handling, etc.) (100\%); cost generated by information flows (communications) and processing of orders (20\%); cost of product servicing and logistic services (28\%); and cost of failures - excessive investment, supplementary cost transferred to third-party partners (suppliers, recipients) and lost profit (5\%). 
Global logistics costs are assessed separately by only $41 \%$ of the respondent companies (Fig. 5), while the external costs of logistics are only separated by $34 \%$ of the studied sample (Fig. 6). The final queries of the survey were designed to evaluate the perceived improvements resulting from the separation of logistics costs in the following areas: cost management, customer service, and production effectiveness: these were confirmed, respectively, by $60 \%, 72 \%$, and $80 \%$ of the respondent companies.

\section{CONCLUSIONS}

The ostensive character of recent changes and trends observed in production companies and their immediate environment, particularly those of the SME segment, and stimulated, among other things, by intense competition, globalisation, and free market progression, has raised the general interest in detailed analyses of cost structures and customer behaviours. Based on the survey's findings, it may be safely concluded that most companies, following the introduction of mechanisms for detailed classifications of their logistics costs, observed tangible improvements in each of the studied aspects, namely: company financial result, quality of customer service, and market position. Thus, the implementation and separation of logistics costs may serve to establish a more detailed image of operations, to facilitate rapid responses to changes in supplies and shipments, and - most of all - to help identify logistic bottlenecks which hamper the flow of goods and materials.

\section{LITERATURE:}

Abt S. (1998) Zarządzanie logistyczne w przedsiębiorstwie, Warszawa: PWE

Beier F.J., Rutkowski K. (1993) Logistyka, Warszawa: SGH

Blaik P. (2001) Logistyka, Warszawa: PWE

Duck O., Krause H., Schulte C. (2001) Gospodarka materiałowa. Praktyczny poradnik, Warszawa: Wyd. ALFA - WEKA Sp. z o.o

Kisperska-Moroń D., Płaczek E., Pinicki R. (2002) Koszty zewnętrzne logistyki $w$ zarządzaniu łańcuchem dostaw, Katowice: Wyd. AE w Katowicach

Kufel M. (1990) Koszty przeplywu materiałów w przedsiębiorstwach przemystowych. Problemy budżetowania, ewidencji i kontroli, Wrocław: PN Akademii Ekonomicznej we Wrocławiu

Kupsch P.U., Linder T. (1985) Materialwirtschaft, Wiesbaden: Heinen

Skowronek Cz., Sarjusz -Wolski Z. (1995) Logistyka w przedsiębiorstwie, Warszawa: PWE

Szałek B. (1994) Logistyka. Wstęp do problematyki, Szczecin: Uniwersytet Szczeciński

Twaróg J. (2003) Koszty logistyki przedsiębiorstw Poznań: Biblioteka logistyka,

Weselik A. (1999) Jak określić koszty logistyki w przedsiębiorstwie, Warszawa: „Logistyka nr 3”

Weselik A. (1993) Wyodrębnienie kosztów logistycznych $w$ przedsiębiorstwie, Warszawa „Problemy Magazynowania i Transportu nr l" 
Figure 2. Logistics costs in separation from other costs

Source: Author's research based on survey results

Figure 3. Plans to introduce such a separation of logistics costs within the next year

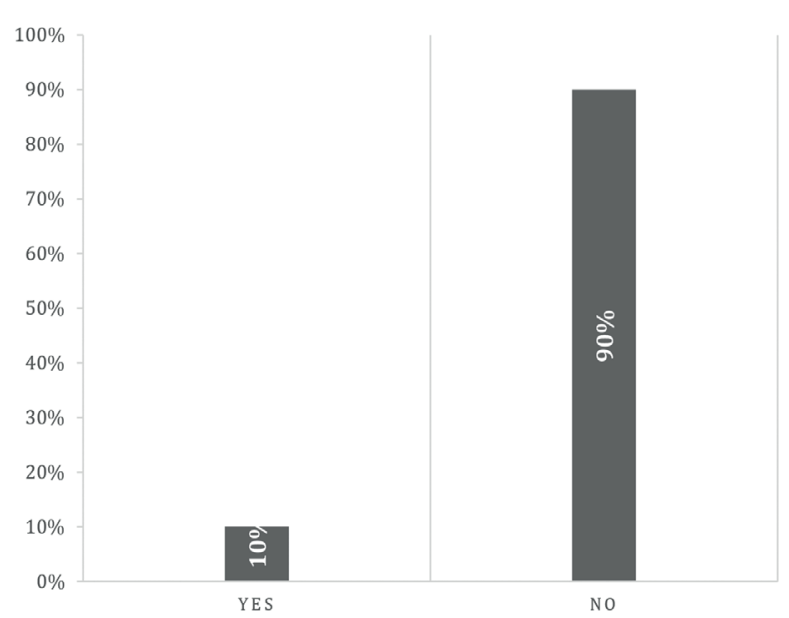

Source: Author's research based on survey results

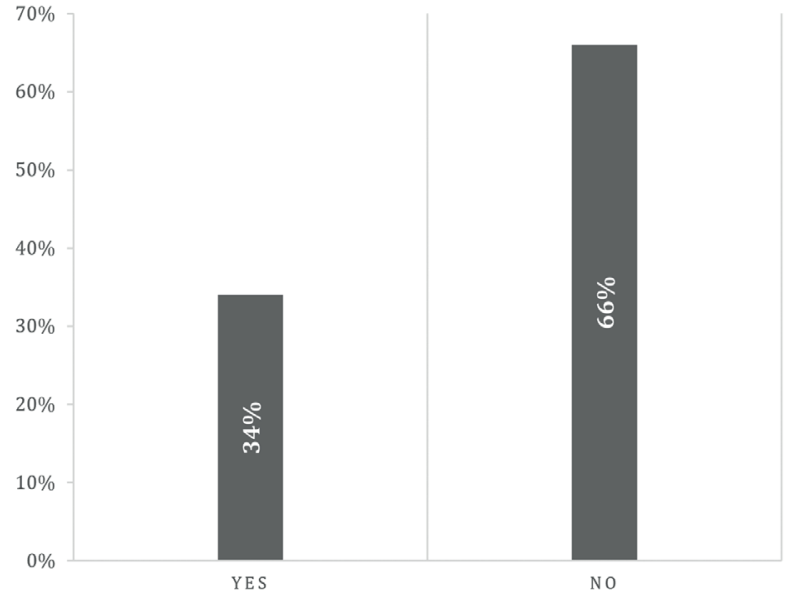

Source: Author's research based on survey results

Figure 5. Utilising the concept of global logistics costs

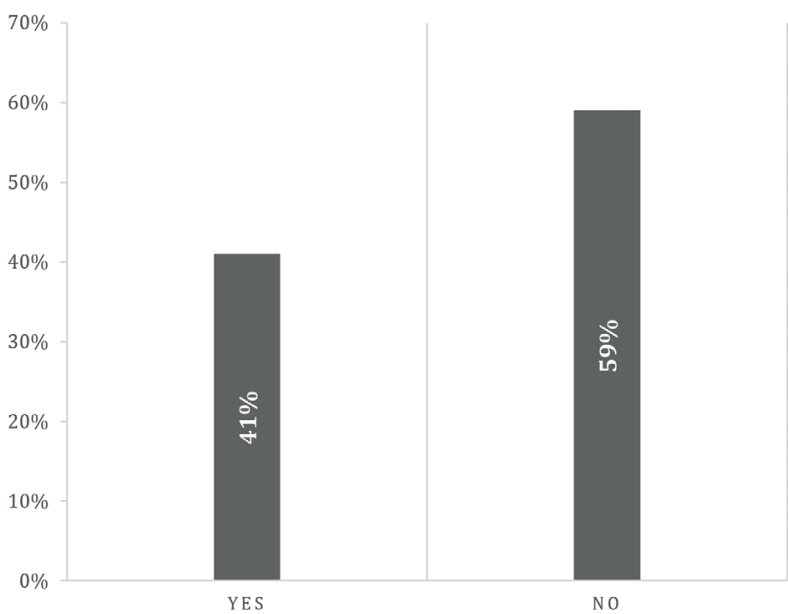

Source: Author's research based on survey results

Figure 6. Does your company separate external costs of logistics

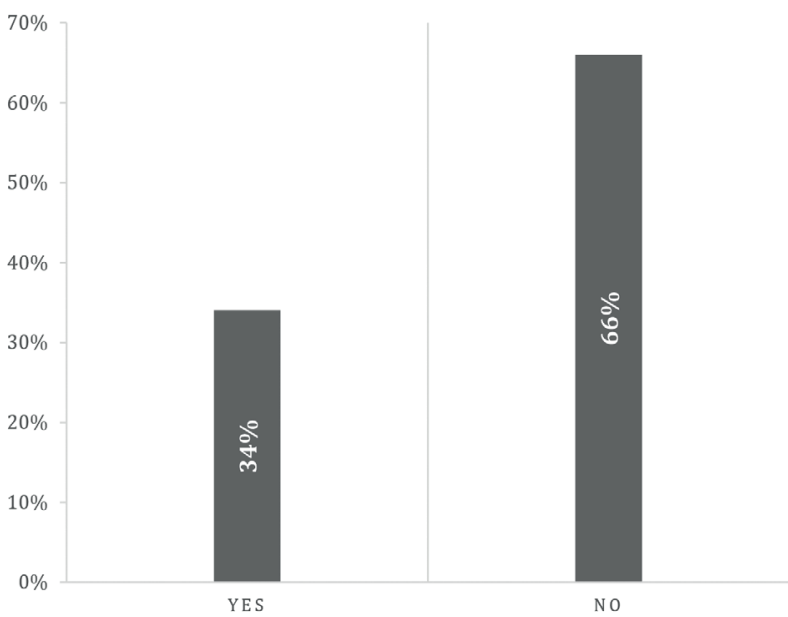

Source: Author's research based on survey results 